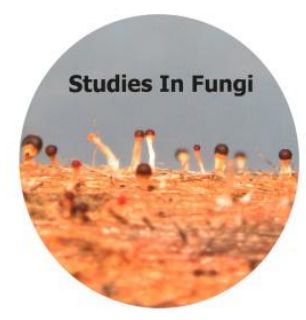

\title{
Article
}

Doi 10.5943/sif/2/1/5

Copyright $\odot$ Mushroom Research Foundation

\section{Ramularia coleosporii (Mycosphaerella) on Plumeria rust in Thailand}

\author{
Sun $\mathrm{JZ}^{1,2}$, Liu $\mathrm{JK}^{3}$, McKenzie $\mathrm{EHC}^{4}$, Liu $\mathrm{XZ}^{1^{*}}$ and Hyde $\mathrm{KD}^{2}$ \\ ${ }^{1}$ Center of Excellence in Fungal Research, Mae Fah Luang University, Chiang Rai, Thailand, 57100 \\ ${ }^{2}$ State Key Laboratory of Mycology, Institute of Microbiology, Chinese Academy of Sciences, No. 3 Park 1, Beichen \\ West Road, Chaoyang District, Beijing, China, 100101 \\ ${ }^{3}$ Guizhou Key Laboratory of Agricultural Biotechnology, Guizhou Academy of Agricultural Sciences, Guiyang, China \\ 550006 \\ ${ }^{4}$ Manaaki Whenua Landcare Research, Private Bag 92170, Auckland, New Zealand.
}

Sun JZ, Liu JK, McKenzie EHC, Liu XZ, Hyde KD 2017 - Ramularia coleosporii (Mycosphaerella) on Plumeria rust in Thailand. Studies in Fungi 2(1), 38-46, Doi 10.5943/sif/2/1/5

\begin{abstract}
A hyperparasitic fungus was found on uredinia of Coleosporium plumeria on leaves of Plumeria rubra in Thailand. The hyperparasite was identified as Ramularia coleosporii following an examination of its morphological characters and a phylogenetic analysis by using ITS sequence data. This is the first record of $R$. coleosporii on $C$. plumeriae in Thailand. Ramularia coleosporii has the potential for biocontrol management strategies of the rust.
\end{abstract}

Key words - biocontrol - Coleosporium plumeriae - fungicolous fungi - hyperparasite

\section{Introduction}

Plumeria is a small tree in the family Apocynaceae. It is commonly known as frangipani, nosegay, or temple tree, and is an ornamental in most tropical and subtropical areas. These trees are commonly found in parks, gardens and landscaped areas in Thailand. They are relatively free from major pests and diseases, however, in the last two decades a rust disease has spread to several parts of the world where Plumeria species are grown, often causing extensive defoliation (Kakishima et al. 1995, Manimohan \& Mannethody 2011). The rust Coleosporium plumeriae Pat. has infected Plumeria in many tropical and subtropical regions (Ogata \& Gardner 1992, Kakishima et al. 1995, Minter et al. 2001, Yang et al. 2006). This rust fungus was first recorded in Thailand on Plumeria acuminata and P. rubra by To-anun et al. (2004).

Coleosporium plumeriae causes extensive yearly leaf loss, but chemical control of a rust fungus on an ornamental host such as Plumeria is not feasible (Moricca \& Ragazzi 2008). Fungal biocontrol agents may therefore be an alternative approach. Some species in the genera Aphanocladium, Cladosporium, Scytalidium, Sphaerellopsis, Tuberculina and Verticillium have been found on the sori of rust fungi, and may be potential biocontrol agents (Moricca and Ragazzi 2008). Recently, Zygosporium gibbum (Sacc. et al.) S. Hughes was found parasitizing C. plumeriae colonies on leaves of Plumeria sp. in India, and it was suggested as a potential biocontol agent (Manimohan \& Mannethody 2011).

The genus Ramularia is the asexual morph of Mycosphaerella (Verkley et al. 2004, Hyde et al. 2013). There are 1152 records of Ramularia in Index Fungorum (2015), many member of this genus have been reported to cause leaf spots. However, three species, Ramularia coleosporii Sacc., $R$. uredinearum Hulea and $R$. uredinicola Khodap. \& U. Braun are found associating with rust 
fungi (Braun 1998, Khodaparast \& Braun 2005). Ramularia coleosporii was original isolated from sori of Coleosporium sp. (Saccardo 1880). It has been considered as a mycoparasite on uredinia of several rust taxa including Coleosporium campanulae and C. petasitis in Austria (Poelt \& FritzSchroeder 1983, Morgan-Jones et al. 1972), C. clematidis, C. clerodendri and Puccinia exhausta in China (Zhang 2006), C. tussilaginis in New Zealand (Braun \& Hill 2002) and C. plumeriae in India (Baiswar et al. 2015). However, there is no report of Ramularia coleosporii being associated with $C$. plumeriae in Thailand.

We collected a Ramularia-like mycoparasite on the sori of C. plumeriae on the leaves of Plumeria rubra in Chiang Rai Province, Thailand. This paper reports its occurrence in Thailand, details its morphological characters and provides a phylogenetic analysis.

\section{Materials \& Methods}

\section{Sampling and morphology}

Rust infected leaves of Plumeria rubra were collected on $2^{\text {nd }} F e b, 2014$ in Chiang Rai Province, Thailand, and were taken to the laboratory in paper bags. Hyphae growing over the uredinia were removed by using a needle, placed in a drop of distilled water on a clean slide and covered by a cover slip. The slides were examined using a Nikon Eclipse 80i compound microscope fitted with a Canon 450D digital camera.

\section{Isolation}

Single spore isolation was carried out following the method described in (Chomnunti et al. 2014). Germinating spores were transferred aseptically to malt extract agar (MEA) plates and grown at $20^{\circ} \mathrm{C}$, then were transferred to Potato Dextrose Agar (PDA) and grown at 25 to $20^{\circ} \mathrm{C}$. Colony colour and other characters on PDA were observed and measured after one week and one month. The specimens are deposited in the Mae Fah Luang University (MFLU) Herbarium (MFLU 16-0944), Chiang Rai, Thailand. Living cultures are also deposited in the Culture Collection in Mae Fah Luang University (MFLUCC 14-0330).

\section{DNA extraction, PCR amplification and sequencing}

Fresh mycelia (50-100 mg) were harvested from 14-day-old cultures grown on PDA media at $25{ }^{\circ} \mathrm{C}$ in $1.5 \mathrm{~mL}$ Eppendorf tubes for genomic DNA extraction. DNA was extracted following the protocol of sequence of internal transcribed spacer (ITS) regions was amplified by polymerase chain reaction (PCR) with the primer pairs ITS5 and ITS4 (White et al. 1990). Each amplification reaction included $0.2 \mathrm{mM}$ of each $\mathrm{dNTP}, 0.4 \mathrm{mM}$ of each primer, $0.5 \mathrm{U}$ of Taq polymerase (Transgen, China), $2 \mu \mathrm{l}$ of genomic DNA solution, $10 \times$ Easy Taq buffer (Transgen, China) in $50 \mu 1$ reaction volume. A typical reaction included an initial denaturation at $95{ }^{\circ} \mathrm{C}$ for $5 \mathrm{~min}$; followed by 35 cycles of denaturation at $95{ }^{\circ} \mathrm{C}$ for $50 \mathrm{~s}$, annealing at $52{ }^{\circ} \mathrm{C}$ for $50 \mathrm{~s}$, extension at $72{ }^{\circ} \mathrm{C}$ for $60 \mathrm{~s}$ and a final extension at $72{ }^{\circ} \mathrm{C}$ for 10 mins. Reactions were run with positive and negative controls to ensure accuracy and to detect contamination. Automated sequencing was performed by Sino Geno Max Co. (Beijing, China).

\section{Phylogenetic analysis}

The closest taxa to our strain were determined with standard nucleotide blast searches, with ITS sequences against the nucleotide database in GenBank (http://www.ncbi.nlm.nih.gov/). The ITS sequence of $R$. cynaraei closest relatives of $R$. coleosporii was selected as ingroup, and Acrodontium crateriforme was employed as outgroup. Multiple sequence alignments were generated with aligned by MAFFT ver. 7.03 using the Q-INS-I strategy (Katoh et al. 2013), Maximum parsimony analyses were conducted with PAUP 4.0b10 (Swofford 2002). Bayesian analysis was performed in a likelihood framework as implemented by MrBayes v3.0b4 software package to reconstruct phylogenetic trees (Huelsenbeck \& Ronquist 2001). The best-fit model of evolution was determined by MrModeltest 2.3 (Posada \& Crandall 1998, Nylander 2004) through 
comparing different nested models of DNA substitution in a hierarchical hypothesis-testing framework. "GTR $+\mathrm{G}+\mathrm{I}$ " was tested as the best model, and parameters were set as follows: lsetnst = 6 , and rates $=$ invgamma; Prset statefreqpr $=$ dirichlet $(1,1,1,1)$. Multiple Bayesian searches using Metropolis-coupled Markov chain Monte Carlo sampling were conducted. One cold and five heated Markov chains were used in the analysis. Bayesian analysis was run for 504000 generations, with trees sampled every 100 generations. The first 1080 trees, which represented the burn-in phase of the analysis, were discarded. To estimate posterior probabilities (PP) of recovered branches (Larget \& Simon 1999) 50\% majority rule consensus trees were created from the remaining trees using PAUP.

Table 1 ITS sequence data used in this study

\begin{tabular}{|c|c|c|c|}
\hline Species & Collection No ${ }^{\mathrm{a}}$. & Origin & Accession No. \\
\hline Acrodontium crateriforme & CBS 144.33 & Contaminant, Netherlands & FN666565 \\
\hline $\begin{array}{l}\text { Mycosphaerella } \\
\text { punctiformis }\end{array}$ & CBS 115297 & & AY853180 \\
\hline M. punctiformis & CBS 115311 & & AY853182 \\
\hline M. punctiformis & CBS 115302 & & AY853183 \\
\hline Ramularia aplospora & CBS 545.82 & & EU040238 \\
\hline R. beticola & $10-R R-35$ & Beta vulgaris, Denmark & JF330025 \\
\hline R. beticola & 09-RR-24 & B. vulgaris, Denmark & JF330018 \\
\hline R. beticola & 10-RR-22 & B. vulgaris, Denmark & JF330013 \\
\hline R. carthami & $s-527$ & USA & DQ466083 \\
\hline R. coleosporii & KACC 42485 & rust on Aster pilosus, South Korea & EF535674 \\
\hline R. coleosporii & Ra_01 & Coleosporium plumeriae, India & KF550285 \\
\hline R. coleosporii & Voucher KACC 42483 & $\begin{array}{l}\text { C. perillae on Perilla frutescens var. } \\
\text { japonica, South Korea }\end{array}$ & EF535672 \\
\hline R. coleosporii & voucher KACC 42484 & $\begin{array}{l}\text { C. eupatorii on Eupatorium chinense } \\
\text { var. simplicifolium, South Korea }\end{array}$ & EF535673 \\
\hline R. coleosporii & $\mathrm{Ra} 02$ & C. plumeriae, India & KF924738 \\
\hline R. coleosporii & voucher KACC 42485 & rust on Aster pilosus, South Korea & EF535674 \\
\hline R. coleosporii & MFUCC 14-0330 & C. plumeriae, Thailand & KP878302 \\
\hline R. collo-cygni & E25 & Hordeum vulgare, Denmark & JN003641 \\
\hline R. collo-cygni & 18.2 & H. vulgare, Denmark & JN003640 \\
\hline R. collo-cygni & $\mathrm{s} 43 / 3$ & H. vulgare, Switzerland & GU939178 \\
\hline R. collo-cygni & $\mathrm{s} 55$ & H. vulgare, Switzerland & GU939172 \\
\hline R. collo-cygni & R7 & H. vulgare, New Zealand & AJ536191 \\
\hline R. collo-cygni & R10 & H. vulgare, New Zealand & AJ536184 \\
\hline R. collo-cygni & R4 & H. vulgare, New Zealand & AJ536178 \\
\hline R. collo-cygni & H12 & H. vulgare, Denmark & JN003642 \\
\hline R. cynarae & CPC 18426 & Cynara cardunculu, USA & HQ728117 \\
\hline R. cynarae & CPC 18725 & C. cardunculus, USA & HQ728118 \\
\hline R. endophylla & CBS 113265 & Quercus robur, Netherlands & JQ739802 \\
\hline R. didyma & 509 & Ranunculus asiaticus, USA & HQ442297 \\
\hline R. endophylla & CBS 113265 & Q. robur, Netherlands & KF251329 \\
\hline R. endophylla & CBS 113265 & Q. robur, Netherlands & KF251220 \\
\hline R. eucalypti & СРC 13046 & Corymbia grandifolia, Italy & EF394861 \\
\hline R. eucalypti & CBS 120726 & C. grandifolia, Italy & EF394860 \\
\hline R. eucalypti & CPC 13304 & Eucalyptus tereticornis, Australia & EF394862 \\
\hline R. lamii & СРC 11312 & Leonurus sibiricus, South Korea & KF251331 \\
\hline R. lamii & CPC 11312 & L. sibiricus, South Korea & KF251222 \\
\hline R. lamii var. lamii & KACC 42534 & L. sibiricus, South Korea & EF535688 \\
\hline R. lamii var. lamii & KACC 42523 & L. sibiricus, South Korea & EF535683 \\
\hline
\end{tabular}


Table 1 (continued)

\begin{tabular}{|c|c|c|c|}
\hline Species & Collection No ${ }^{a}$. & Origin & Accession No. \\
\hline R. lamii var. lamii & KACC 42511 & L. sibiricus, South Korea & EF535676 \\
\hline R. miae & CBS 120121 & $\begin{array}{l}\text { Wachendorfia thyrsifolia, South } \\
\text { Africa }\end{array}$ & DQ885902 \\
\hline R. pratensis & F0709 & Malus x domestica_Fuji, Japan & AB693924 \\
\hline R. pratensis & CPC 11294 & Rumex crispus, South Korea & KF251223 \\
\hline R. pratensis & s89 & Rumex sp., Germany & GU939182 \\
\hline R. pratensis var. pratensis & CPC 11294 & R. crispus, South Korea & EU019284 \\
\hline R. proteae & CPC 18294 & Physalis longifolia, Australia & JN712499 \\
\hline R. proteae & CBS 112161 & P. longifolia, Australia & EU707899 \\
\hline R. rumicis-crispi & voucher CEO06 & Rumex japonicus, Taiwan & JN662315 \\
\hline R. sphaeroidea & STE-U 5242 & & AY352584 \\
\hline R. stellenboschensis & clone NY218 & Pinus radiata, Australia & HQ442297 \\
\hline R. stellenboschensis & CBS 130600 & Protea sp., South Africa & KJ406791 \\
\hline R. uredinicola & IRAN & $\begin{array}{l}\text { Melampsora sp. on Salix babylonica, } \\
\text { Iran }\end{array}$ & GU939180 \\
\hline R. uredinicola & CPC 10813 & Salix sp., South Korea & GU214694 \\
\hline R. vizellae & CPC 18283 & $\begin{array}{l}\text { Protea sp., in association with Vizella } \\
\text { interrupta, South Africa }\end{array}$ & JN712500 \\
\hline
\end{tabular}

Note: aCBS = Centraalbureauvoor Schimmelcultures, Netherlands; KACC $=$ Korean Agricultural Culture Collection, Korea; MFLUCC = Mae Fah Luang University Culture Collection. The others from the personal Culture Collection.

\section{Results}

\section{Phylogenetic analyses}

Nucleotide sequence blast searches of the NCBI-nrDNA database, showed that isolate MFLUCC 14-0330 had 99\% ITS sequence similarity with Ramularia coleosporii, and showed high similarity with other species in Ramularia.

The combined ITS dataset comprised of 53 taxa (Table 1) including isolate MFLUCC 140330 with $A$. crateriforme as the out group taxon. The analysis of Maximum parsimony consisted with total 468 characters, 272 constant characters, 149 parsimony informative and 47 variable characters parsimony uninformative. The Bayesian tree has the similar topology with the best Maximum parsimony tree. The values of the Bayesian posterior probabilities (PP) (equal to or above 95\%) from MCMC analyses are shown (Fig. 3). Bootstrap support (BS) values of MP (equal to or above $50 \%$ based on 1000 replicates) were shown. According to the phylogenetic analyses, our strain (MFLUCC 14-0330) formed a subclade with other $R$. coleosporii and showed strong high Bootstrap value (85\%). These fungicolous $R$. coleosporii could also form a clade with $R$. uredinicola which was another fungicolous fungus of rust fungi and separated from representative species of the genus, however, the value of BS and PP are low.

Ramularia coleosporii Sacc., Michelia 2 (6): 170, t. 983 (1880)

Figs 2, 3

MycoBank 163652; Facesoffungi number: FoF 00752

Parasitic on colonies of Coleosporium plumeriae on leaves of Plumeria spp (Fig. 2). Colonies effuse whitish, mycelium 1.5-3.0 $\mu \mathrm{m}$ wide, superficial and immersed, sparingly branched, septate smooth, hyphae septate, subhyaline. Stroma, hyphopodia and setae absent. Sexual morph: undetermined. Asexual morph: Conidiophores 35-135 × 3-5 $\mu \mathrm{m}$, macronematous, mononematous, arising from hyphae immersed in uredisporw, or occasionally solitary, arising from superficial hyphae, erect, straight, subcylindrical to geniculate-sinuous, unbranched or branched. Conidiogenous cells 10-20 $\times 2-3 \mu \mathrm{m}$, discrete, subulate, gradually tapering to $4 \mu \mathrm{m}$ wide near the apex, one or two scar on the apex, hyaline. Conidia 6-28 $\times 4-6 \mu \mathrm{m}$, catenate, in simple or branched chains, ellipsoid-ovoid, fusiform, old conidia sometimes with 1-4 conspicuous hila. 
Culture characteristics - Colonies on PDA slow growing, hyaline when young, light greyish at maturity (Fig 3, a), raised on surface, with the mycelium composed of septa, branched hyphae, formed in abundance, after $30 \mathrm{~d}, 0.5 \mathrm{~cm}$ diameter at $25^{\circ} \mathrm{C}$. Colonies effuse whitish, mycelium superficial and immersed, sparingly branched, septate smooth, hyphae septate, subhyaline. Conidiophores 35-140 × 3-4 $\mu \mathrm{m}$, unbranched, straight or flexuous, hyaline. Conidiogenous cells 15-26 $\times 3-4 \mu \mathrm{m}$, discrete, subulate, 1 or 3 scar on the apex. Conidia $6-26 \times 4-6 \mu \mathrm{m}$, catenate, in simple or branched chains, ellipsoid-ovoid, fusiform, old conidia sometimes with 1-4 conspicuous hila.

Specimen examined - Thailand, Chiang Rai Province, Chiang Rai city, on colony of Coleosporium plumeriae on leaves of Plumeria rubra. MFLU15-033, living culture in MFLUCC10-0064; ROMANIA, Distr. Mures, Sovata Bâl, on Senecio doria subsp. umbrosus CBS H-17708, CBS H-17709; ROMANIA, Distr, Prahova, Busteni, Valea Jepilor, on leaves of Petasites kablikianus CBS H-17710.

Notes - Ramularia coleosporii was original isolated from sori of Coleosporium sp. (Saccardo 1880). It has been considered as a mycoparasite on uredinia of several rust taxa in Austria (Poelt \& Fritz-Schroeder 1983, Morgan-Jones et al. 1972), China (Zhang 2006), New Zealand (Braun \& Hill 2002) and India (Baiswar et al. 2015). This specimen was collected from Chiang Rai on colony of Coleosporium plumeriae on leaves of Plumeria rubra. Compared with the Ramularia species associated with rust fungi, our collection has the similar morphological traits of Ramularia coleosporii. Meanwhile the phylogenetic analyses also affiliated our isolate to Ramularia coleosporii.

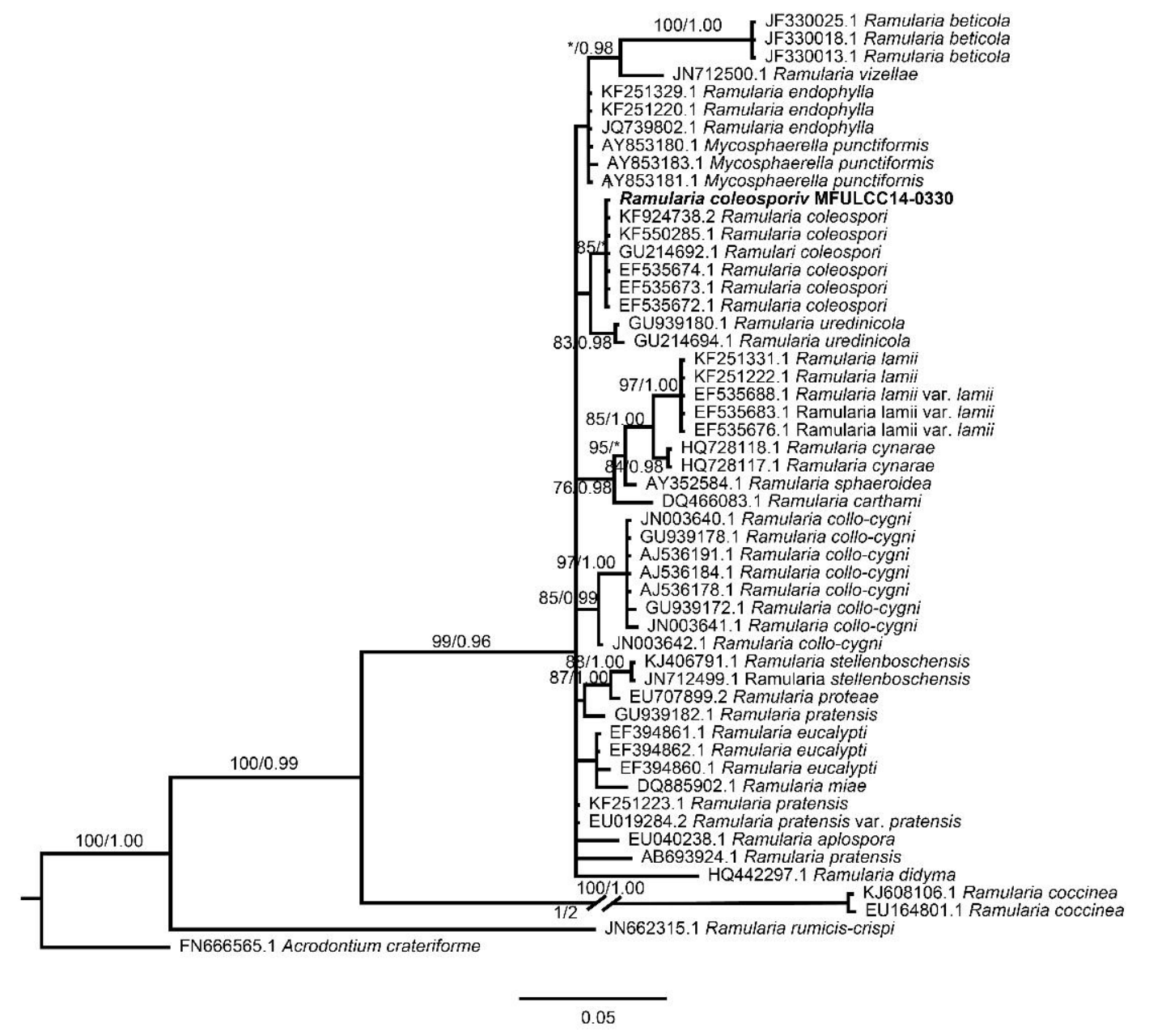

Fig. 1 - Phylogram inferred from likelihood analysis using ITS sequences. Bootstrap support values for maximum likelihood (ML) higher than 50\% are defined. Bayesian posterior probabilities (BYPP) greater than 0.95 are provided. 

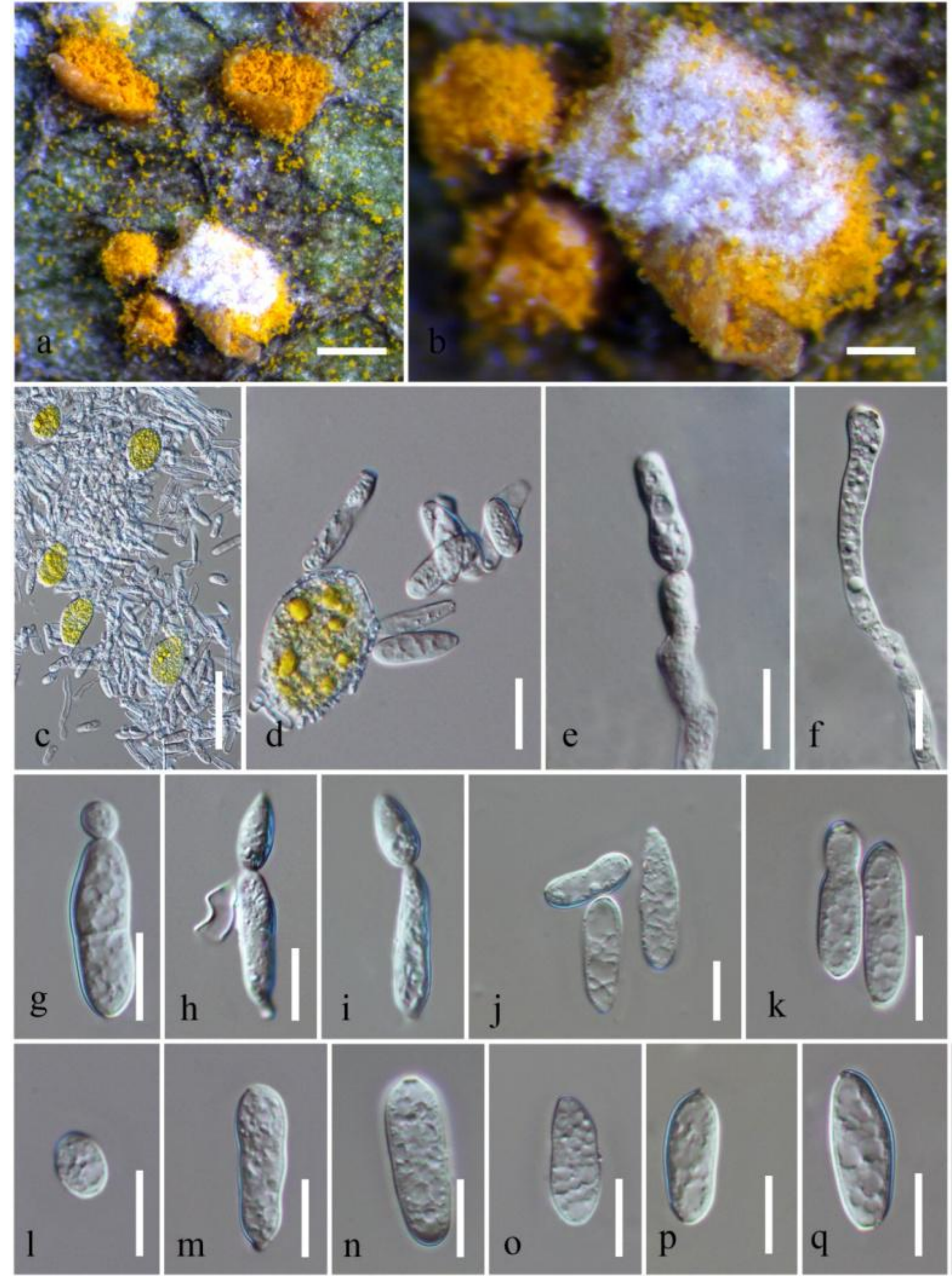

Fig. 2 - Ramularia coleosporii. a, b Colony on uredinia of C. plumeriae on Plumeria rubra leaf. c $\mathrm{d}$ conidia and rust urediniospores. e Conidiophore with conidium. f Conidiophore without conidia; g, q Conidia. Scale bars: $\mathrm{a}=500 \mu \mathrm{m}, \mathrm{b}=200 \mu \mathrm{m}, \mathrm{c}=50 \mu \mathrm{m}, \mathrm{d}-\mathrm{q}=10 \mu \mathrm{m}$. 

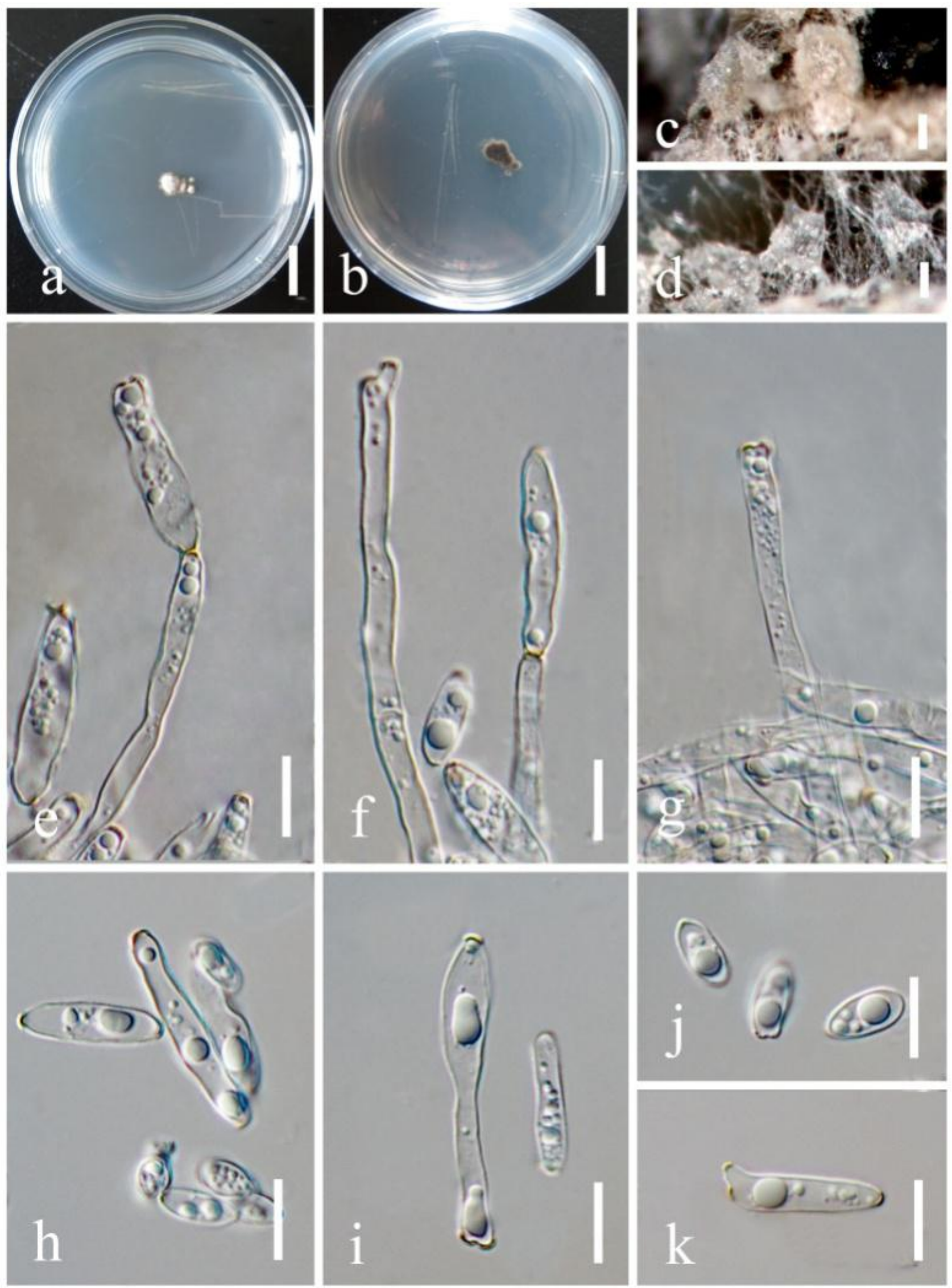

Fig. 3 - Ramularia coleosporii on PDA. a, b Thirty-day-old colony on PDA. c, d Hyphae on PDA, e, $f$ Conidiophores with conidia. g Conidiophore without conidia. h, k Conidia. Scale bars: $a, b=1$ $\mathrm{cm}, \mathrm{c}, \mathrm{d}=100 \mu \mathrm{m}, \mathrm{e}-\mathrm{k}=10 \mu \mathrm{m}$. 


\section{Discussion}

Ramularia species are mostly leaf pathogens, with only three species found in uredinia of rust fungi. Based on the morphological characters and phylogenetic analyses, our strain was determined to be $R$. coleosporii. Ramularia coleosporii showed a close relationship with another fungicolous species, $R$. uredinicola. However, there are differences in the size of conidiophores and conidia. $R$. coleosporii has conidiophores that measure 35-135 $\times 3-5 \mu \mathrm{m}$ and conidia that are 6-28 $\times 4-6 \mu \mathrm{m}$ in size, whereas the conidiophores of $R$. uredinicola are 20-80 $\times 2-4 \mu \mathrm{m}$ and the conidia are 4-15 $\times 2-4 \mu \mathrm{m}$ in size (Khodaparast and Braun 2005). The third fungicolous species, Ramularia uredinearum produces consistently colorless colonies on its rust host (Braun 1998), but its conidia are, 9-24 × 3-5 $\mu \mathrm{m}$ in size, they are slightly shorter and thinner than $R$. coleosporii (Zhang 2006). However, the molecular data is not available for $R$. uredinearum, the phylogenetic relationships between $R$. coleosporii, $R$. uredinicola and $R$. uredinearum need be further studied.

Ramularia colesporii has been reported as a pathogen on leaves of Campanula rapunculoides in Armenia (Simonyan 1981), Clematis gouriana in China (Poelt \& Fritz-Schroeder 1983), Ipomoea batatas in Puerto Rico (Stevenson 1975), and Perilla frutescens var. acuta in China (Yang 2005). It is unclear if the species referred to in these reports is correctly named as substantiating molecular data is lacking. Here, we firstly report $R$. colesporii associated with $C$. plumeriae on the leaves of Plumeria sp. in Chiang Rai, Thailand. There are no reports of $R$. colesporii causing leaf spot disease of Plumeria and thus this hyperparasite may be a potential agent for biocontrol of Plumeria rust.

\section{Acknowledgements}

This research was supported by the Natural Science Foundation of China (No. 31600024)

\section{References}

Baiswar P, Ngachan S, Chandra S. 2015 - Ramularia coleosporii, a hyperparasite on Coleosporium plumeriae in India. Journal of Phytopathology 163, 407-410.

Braun U. 1998 - A monograph of Ramularia, Cercosporella and allied genera (phytopathogenic hyphomycetes). IHW-Verlag, Eching.

Braun U, Hill CF. 2002 - Some new micromycetes from New Zealand. Mycologcal Progress 1, 1930 .

Chomnunti P, Hongsanan S, Aguirre-Hudson S, Tian Q, Peršoh D, Dhami MK, Alias AS, Xu JC, Liu XZ, Stadler M, Hyde KD. 2014 - The sooty moulds. Fungal Divercity 66, 1-36.

Huelsenbeck JP, Ronquist F. 2001 - MRBAYES: Bayesian inference of phylogenetic trees. Bioinformatics 17(8), 754-755.

Hyde KD, Jones EBG, Liu JK Ariyawansa HA, Boehm E, Boonmee S, Braun U, Chomnunti P, Crous PW, Dai DQ, Diederich P, Dissanayake A, Doilom M, Doveri F, Hongsanan S,. Jayawardena R, Lawrey JD, Li YM, Liu YX, Lücking R, Monkai J, Muggia L, Nelsen MP, Pand KL, Phookamsak R, Senanayake IC, Shearer CA, Suetrong S, Aguirre-Hudson B, Alias AS, Aptroot A, Bahkali AH, Bezerra JL, Bhat DJ, De Hoog S, Kang JC, Knudsen K, Li WJ, Li XH, Liu ZY, Mapook A, McKenzie EHC, Miller AN, Mortimer PE, Phillips AJL, Raja HA, Scheuer C, Schumm F, Taylor JE, Tian Q, Tibpromma S, Wanasinghe DN, Wang Y, Xu JC, Yacharoen S, Yan JY, Zhang M. 2013 - Families of Dothideomycetes. Fungal Divercity $63,1-313$.

Index Fungorum http://www.indexfungorum.org/Names/Names.asp (accessed July 2015).

Kakishima M, Kobayashi T, McKenzie EHC. 1995 - A warning against invasion of Japan by the rust fungus, Coleosporium plumeriae, on Plumeria. Forest Pests 44, 144-147.

Katoh K, Standley DM. 2013 - MAFFT multiple sequence alignment software version 7: improvements in performance and usability. Molecular biology and evolution 30(4), 772-780.

Khodaparast A, Braun U. 2005 - Ramularia uredinicola - a new species from Iran. Mycotaxon 91, 357-360. 
Larget B, Simon DL. 1999 - Markov chain Monte Carlo algorithms for the Bayesian analysis of phylogenetic trees. Molecular Biology and Evolution 16, 750-759.

Manimohan P, Mannethody S. 2011 - Zygosporium gibbum: a new and remarkable rust hyperparasite. Mycosphere 2, 219-212.

Minter DW, Hernández MR, Mena OJ. 2001 - Fungi of the Caribbean: an annotated checklist, PDMS Publishing Isleworth.

Morgan-Jones G, Raj TRN, Kendrick B. 1972 - Genera coelomycetarum. VI. Kellermania. Canadian Journal of Botany 50, 1641-1648.

Moricca S, Ragazzi A. 2008 - Biological and integrated means to control rust diseases. In Integrated management of diseases caused by fungi, Phytoplasma and Bacteria. A. Ciancio, K.G. Mukerji.

Nylander JAA. 2004 - MrModeltest v2. Program distributed by the author. Evolutionary Biology Centre, Uppsala University, 2.

Ogata D, Gardner DE. 1992 - First report of Plumeria rust, caused by Coleosporium plumeriae, in Hawaii. Plant Disease 76, 642.

Poelt J, Fritz-Schroeder J. 1983 - Ramularia und verwandte Pilze in der Steiermark, (eine erste Übersicht) Mitt. natuawiss. ver. Steiermark 113, 79-89.

Posada D, Crandall KA. 1998 - Modeltest: testing the model of DNA substitution. Bioinformatics, 14(9), 817-818.

Saccardo PA 1880 - Conspectus generum fungorum Italiae inferiorum. Michelia 2, 170.

Simonyan S 1981 - Mycoflora of the botanic gardens and arboreta of the Armenian SSR. Hayka, Armenia.

Stevenson JA. 1975 - Fungi of Puerto Rico and the Virgin Islands. Contributions of the Reed Herbarium 23, 1-742.

Swofford DL. 2002 - PAUP*. Phylogenetic analysis using parsimony (* and other methods). Version 4. Sinauer Associates, Sunderland.

To-anun C, Visarathanonth P, Engkhaninun J, Kakishima M. 2004 - First report of Plumeria rust, caused by Coleosporium plumeriae, in Thailand. Natural History 4, 41-46.

Verkley GJM, Crous PW, Groenewald JZ, Braun U, Aptroot A. 2004 - Mycosphaerella punctiformis revisited: morphology, phylogeny, and epitypification of the type species of the genus Mycosphaerella (Dothideales, Ascomycota). Mycological Research 108, 1271-1282.

White TJ, Bruns T, Lee S, Taylor JW. 1990 - Amplification and direct sequencing of fungal ribosomal RNA genes for phylogenetics. In PCR protocols: a guide to methods and applications. Innis, M.A., D.H. Gelfand, J.J. Sninsky, and T.J. White. Academic Press, Inc.

Yan J, Wu PS, Shi ZW, Wu Y. 2006 - A new record of Coleosporium (Uredinales ) in China. Mycosystema 25, 327-328.

Yang, ZL. 2005 - Diversity and biogeography of higher fungi in China. In Evolutionary genetics of fungi. J.P. Xu, Horizon Bioscience.

Zhang ZY. 2006 - Botrytis, Ramularia, Flora fungorum sinicorum Vol. 26 Science Press, Beijing. 